\title{
Factors Influencing Job Satisfaction: The Case of Agriculture Department of Tanah Datar Regency
}

\author{
Elsa Fitri ${ }^{1}$, Deri ${ }^{2}$, Syamsul Amar ${ }^{3}$, Abror Abror ${ }^{4}$ \\ ${ }^{1}$ Faculty of Economics, Universitas Negeri Padang, Padang, Indonesia \\ $\bowtie$ (e-mail) elsa.fitri@gmail.com \\ ${ }^{2}$ Faculty of Economics, Universitas Negeri Padang, Padang, Indonesia \\ $\triangle$ (e-mail) deri_84@yahoo.com \\ ${ }^{3}$ Dept. of Economics, Faculty of Economics, Universitas Negeri Padang, Padang, Indonesia \\ $\triangle$ (e-mail) syamsulamar@yahoo.co.id \\ ${ }^{4}$ Dept. of Management, Faculty of Economics, Universitas Negeri Padang, Padang, Indonesia \\ $\bowtie$ (e-mail) abror094@gmail.com
}

\begin{abstract}
Human resources are a contribution to the growth and development of the organization. The achievement in organization is determined by the role of human resources quality. This study aims to analyze and explain the significant influence of leadership on working climate, leadership on work motivation, working climate on work motivation, work motivation on job satisfaction, and indirect influence of leadership on job satisfaction and indirect influence of working climate on job satisfaction. This study used quantitative approach through questionnaire with the help of 105 employees in the Agriculture Department of Tanah Datar Regency as respondents. Data analysis used was descriptive analysis and path analysis with t-test as hypothesis testing. The results of research show that leadership has a significant influence on working climate, leadership has a significant influence on work motivation, working climate has a significant influence on work motivation, work motivation has a significant influence on job satisfaction, leadership has a significant influence on job satisfaction and working climate has a significant influence on job satisfaction.
\end{abstract}

Keywords: leadership, working climate, and job satisfaction

\section{Introduction}

Human factor in organization is a factor that is very capable in providing a dominant and determining role in an effort to achieve the goals of the organization. It means that human resources determine the success or failure of organization. Organization must understand that human resources are an integral part of its success. The productivity of organization depends on the individual job satisfaction within the organization. Job satisfaction is also very important to be noted. High job satisfaction is needed in every effort to achieve organization goals because the achievement of organization goals is the hope of every organization. Conversely, low employee satisfaction is an obstacle in achieving organization goals.

Dissatisfaction is the starting point of problems arising from the organization, such as absenteeism, superior and subordinate conflicts, and many other problems that cause disruption of the process of achieving organization goals. The existence of high job satisfaction will emerge a positive bond between worker and his work, so that from this worker can be expected an optimal result. According to Setiawan (2006), "job satisfaction is a pleasing or positive emotional state comes from a person's assessment of his work or his work experience." Job satisfaction is influenced by many organizational factors ranging from salary, job security, workplace conditions, and leadership.

According to Ho, Ross, and Coutts (2016), leadership is a process of organizational effectiveness through the way leaders mobilize followers so that they participate in efforts to achieve organization goals. Based on the statement above, leadership is the way a leader directs subordinates, so they can cooperate productively. Without effective leadership, individuals and groups tend to have no 
direction, no satisfaction, and less motivation. Leadership at the Agriculture Department of Tanah Datar Regency is still not fully supported employees' job satisfaction. Leaders were still not effective in giving guidance and direction related to the work of employees, employees were also not satisfied with the leader's role primarily in terms of decision-making, leaders did not discuss with employees about the decision making. Besides, leaders also did not explain new duty to employees.

Improper interaction between the leader and the employee can have a negative impact on employee job satisfaction and can lead to stress and reluctance to go to work, which can lead to high costs to the organization as a result of reduced productivity, increasing absenteeism and turnover. In this case, leaders are hinted to give priority to a collegial and supportive relationship, in which the involvement of staff or followers is more prominent, and the level of freedom is wider.

According to Wirawan (2007), working climate of organization is the atmosphere of work environment within an organization or company. The working climate is the perception of organizational members (individually or in group) and those who are constantly in touch with organizations (e.g. suppliers, consumers, consultants and contractors) on what exists and happens within the organization's internal environment on a regular basis, which influences attitudes and organizational behavior and the performance of organizational members which then determines the performance of organization.

Open organizational climate encourages employees to express their interests and dissatisfactions without fear of retaliation and attention. Such dissatisfaction can be dealt with a positive and wise way. A climate of openness and support can create employee motivation (Vansteenkiste, Simons, Lens, Sheldon \& Deci, 2004).

Work motivation can be defined as a psychological impulse to a person which determines the direction of behavior, level of effort, and level of persistence of someone in an agency. Thus, work motivation can be interpreted as an employee's spirit at work that enables employees to work to achieve goals (George and Jones, 2005). A study conducted by Kakkos et al. (2010) in the banking industry found that motivation has a positive effect on job satisfaction of bank employees. The type of research was quantitative method with multiple analytical techniques through means of observation, questionnaire and documentation study.

The research hypotheses of this study are:

$\mathrm{H}_{1}$ leadership has a significant influence on employee working climate

$\mathrm{H}_{2}$ leadership has a significant influence on work motivation

$\mathrm{H}_{3}$ leadership has significant influence on job satisfaction

$\mathrm{H}_{4}$ working climate has significant influence on work motivation

$\mathrm{H}_{5}$ working climate has a significant influence on job satisfaction

$\mathrm{H}_{6}$ work motivation has a significant influence on job satisfaction

\section{Methods}

The population of this research was all employees at the Agriculture Department of Tanah Datar Regency. The total population was 145 employees and they all have status as civil servants. A sample is a part of the population to be observed which will be used as an estimate. This research used stratified proportional random sampling method. The sample size was determined using the Cochran formula resulted with 55 employees.

The type of data in this study was subject data. Sources of data used in this study were primary data collected through a survey questionnaire which had been given scores according to Likert-scale rules. In this study, data collection techniques used were field study and documentation technique. In addition, this study also used secondary data. The instrument to collect data in this research was a questionnaire prepared by using Likert scale. 
Table 1 The research questionnaire grid

\begin{tabular}{|c|c|c|}
\hline No & Variable & Indicator \\
\hline 1 & Work Satisfaction (Y) & $\begin{array}{ll}\text { - } & \text { Work itself } \\
\text { - } & \text { Responsibility } \\
\text { - } & \text { Supervision } \\
\text { - } & \text { Company policy }\end{array}$ \\
\hline 2 & Work Motivation (X3) & $\begin{array}{ll}\text { - } & \text { Need for achievement } \\
\text { - } & \text { Need for power } \\
\text { - } & \text { Need for affiliation }\end{array}$ \\
\hline 3 & Working Climate (X2) & $\begin{array}{ll}\text { - } & \text { Autonomy } \\
\text { - } & \text { Opportunity to grow } \\
\text { - } & \text { Recognition }\end{array}$ \\
\hline 4 & Leadership (X1) & $\begin{array}{ll}\text { - } & \text { Delivering } \\
\text { - } & \text { Selling } \\
\text { - } & \text { Participating } \\
\text { - } & \text { Delegating }\end{array}$ \\
\hline
\end{tabular}

Before using the instrument, trials should be performed to obtain valid and reliable statement items, then validation and reliability tests are performed. Validity and reliability tests were done using computer aid through SPSS (statistical product service solution) version 20. Normality test was done by using statistical parametric by using Kolmogorov-Smirnov method. Homogeneity tests were used to test the homogeneity of variance occurring in population groups, so that the data obtained from the sample were believed as one unity. To answer the hypotheses in the research, path analysis technique was used. To perform the stages of hypothesis testing, direct and indirect effects testing stages were used. The results of the normality test can be seen in Table 2 below.

Table 2 The summary of normality test of research variables

\begin{tabular}{lccc}
\hline \multicolumn{1}{c}{ Variable } & Sig. Probability & Alpha & Distribution \\
\hline Job Satisfaction $(\mathrm{Y})$ & 0.372 & 0.05 & Normal \\
Leadership $\left(\mathrm{X}_{1}\right)$ & 0.549 & 0.05 & Normal \\
Working Climate $\left(\mathrm{X}_{2}\right)$ & 0.296 & 0.05 & Normal \\
Work Motivation $\left(\mathrm{X}_{3}\right)$ & 0.569 & 0.05 & Normal \\
\hline
\end{tabular}

From Table 2, it is known that the significance value of job satisfaction is 0.372 , leadership is 0.549 , working climate is 0.296 , and work motivation is 0.569 . This means that the score of each variable is greater than the 0.05 significance level. Thus, it can be stated that the distribution of data was derived from samples that were normally distributed.

The data homogeneity testing was done by using spearmen correlation formula. As a basis for denial or acceptance of homogeneity data is a 0.05 significance level. If sig value $>0,05$ then the data are homogeneous, vice versa if sig value $<0,05$ then data are not homogeneous. The results of homogeneity test can be seen in table 3 below:

Table 3 The summary of homogeneity test of research variables

\begin{tabular}{lll}
\hline Variable & Sig. Probability & Description \\
\hline Leadership $\left(\mathrm{X}_{1}\right)$ & 0.862 & Homogeneous \\
Working Climate $\left(\mathrm{X}_{2}\right)$ & 0.761 & Homogeneous \\
Work Motivation $\left(\mathrm{X}_{3}\right)$ & 0.899 & Homogeneous \\
\hline
\end{tabular}

Table 3 describes the score of each variable, leadership variable $\left(X_{1}\right)$ is 0.862 , working climate variable $\left(\mathrm{X}_{2}\right)$ is 0.761 , and work motivation variable $\left(\mathrm{X}_{3}\right)$ is 0.899 . Based on the significant probability, it can be concluded that the distribution of data came from a homogeneous sample, so it can be continued for hypothesis testing analysis. 
Path analysis is used to see the effect of independent variables on dependent variables through other independent variables and measure the direct and indirect influences of a variable on other variables. After performing the normality and homogeneity tests, then the research was continued by conducting path analysis.

The first analysis was conducted to examine the influence of leadership $\left(\mathrm{X}_{1}\right)$ on working climate $\left(\mathrm{X}_{2}\right)$ in Agriculture Department of Tanah Datar Regency. Based on the analysis results, path coefficient $\mathrm{pX}_{2} \mathrm{X}_{1}=0.546$ which indicates that the direct influence of leadership on working climate is $0.546 \times 0.546=0.298$ or $29.8 \%$. The F-test show a significance level of $0.000(\alpha=0,05)$. Hence, there is a significant influence between leadership and working climate. The path coefficient of leadership variable $(\mathrm{Px} 1 \times 2)=0.546$ with F-cal $=43.650$ on sig. 0.000 . The influence of other variables on working climate $\left(\mathrm{X}_{2}\right)$ is: $(0.84)^{2} \times 100 \%=71 \%$.

The second analysis was done and the results show that the path coefficient $\mathrm{pX}_{3} \mathrm{X}_{1}=0.297$ shows that the direct influence of leadership on work motivation is $0.297 \times 0.297=0.089$ or $8.9 \%$. The path coefficient of $\mathrm{pX}_{3} \mathrm{X}_{2}=0.412$ which shows that the direct effect of working climate on work motivation is $0.412 \times 0.412=0.170$ or $17 \%$.

The results indicate a coefficient of determination $\left(\mathrm{R}_{2}\right)$ of 0.392 which implies that leadership and working climate can explain around $39.2 \%$ changes in work motivation. The significance value of each independent variable on the dependent variable is as follows. The influence of leadership on work motivation has a significant value of 0.002 . Further, the influence of working climate on work motivation has a significant value of 0.000 .

The third analysis was conducted with the results as follows. Path coefficient pYX $1=0.267$ indicates that the direct influence of leadership on job satisfaction is $0.267 \times 0.267=0.071$ or equal to $7.13 \%$. Path coefficient $\mathrm{pYX}_{2}=0.238$ indicates that the direct influence of working climate on job satisfaction is $0.238 \times 0.238=0.056$ or equal to $5.66 \%$. Path coefficient $\mathrm{pYX} \mathrm{X}_{3}=0.348$ indicates that the direct influence of work motivation on job satisfaction is $0.348 \times 0.348=0.121$ or equal to $12.1 \%$. further, a coefficient of determination (R2) of 0.510 implies influence of leadership, working climate and work motivation on job satisfaction is $51 \%$. Finally, the significance value of each independent variable on the dependent variable is as follows. The influence of leadership $\left(\mathrm{X}_{1}\right)$ on work motivation $\left(X_{2}\right)$ has a significant value of 0.003 . The influence of working climate $\left(X_{2}\right)$ on work motivation $\left(X_{3}\right)$ has a significant value of 0.010 . The influence of work motivation $\left(\mathrm{X}_{3}\right)$ on job satisfaction $(\mathrm{Y})$ is 0.000 .

The influence of independent variables on the dependent variable in this study has been proved homogeneous. So, that the prerequisite to perform the path analysis has been fulfilled. The influence of other variables on job satisfaction $(\mathrm{Y})$ is: $(0.7)^{2} \times 100 \%=49 \%$.

\section{Results and Discussion}

\section{The Influence of Leadership on Working Climate}

Based on the analysis it is found that leadership has a significant influence on the working climate in the Agriculture Department of Tanah Datar Regency. This indicates that, if leadership in an organization is effective, the working climate will also be conducive, and vice versa. Leadership variable is formed by four indicators, namely (1) delivering, (2) selling, (3) participating, (4) delegating. From these four indicators, it can be seen that the delivering indicator was in adequate category, while the indicators of selling, participating and delegating were in poor category. This means that the leadership of Agriculture Department of Tanah Datar Regency has not been effective. It certainly will also result in an unconducive working climate in the Agriculture Department.

This is relevant with Parker et al. (2003) which state that the working climate is produced by leadership. Wirawan $(2008,132)$ also states that one of the factors which influences the working climate is the pattern of leadership. 


\section{The Influence of Leadership on Job Satisfaction}

Based on the analysis, it is found that leadership has a significant influence on job satisfaction in the Agriculture Department of Tanah Datar Regency. This indicates, the better the role of leadership, the better the job satisfaction. Leadership is closely related with employee job satisfaction. Leadership which gets positive response from employees tends to increase employee job satisfaction, and vice versa.

This is relevant with Luthans (2006) who states that one of dimensions of job satisfaction is supervision, supervision in this case is supervision carried out by the leadership. The more effective supervision is, the more comfortable employees to the supervision, and hence employee job satisfaction will be higher.

\section{The Influence of Working Climate on Work Motivation}

Based on the analysis, it is found that the working climate had a significant influence on the work motivation in the Department of Agriculture of Tanah Datar Regency. This indicates the more conducive working climate, the higher work motivation of the employees of the Department of Agriculture of Tanah Datar regency will be. This is relevant to Mc Clellend's opinion in Hasibuan $(2001,129)$ which state that work motivation is influenced by the working climate.

\section{The Influence of Working Climate on Job Satisfaction}

Based on the analysis, it is found that working climate had significant influence on job satisfaction in the Agriculture Department of Tanah Datar Regency. This indicates, the more conducive working climate, the higher employees' job satisfaction will be. This is relevant to the opinion of Davies et al. (2006) which state that job satisfaction is influenced by the work environment.

\section{The Influence of Work Motivation on Job Satisfaction}

Based on the analysis, it is found that work motivation has a significant influence on job satisfaction in the Agriculture Department of Tanah Datar Regency. This shows, the higher employees' work motivation, the higher employees' job satisfaction in Agriculture Department of Tanah Datar Regency will be.

This is relevant to Hasibuan (2007) who defines motivation as the driving force that creates the enthusiasm of one's work so that they are willing to cooperate, work effectively, and integrated with all their efforts to achieve satisfaction. Frederick Herzberg's two factors motivation theory states that there are two factors that can give satisfaction at work, dis-satisfiers factor (the salary, the company policy, the status, and the interpersonal relationship) and satisfiers factor (the achievement, the rewards, the promotions, the work environment, and the job itself).

\section{Conclusions}

This study aims to analyze and explain the significant influence of leadership on working climate, leadership on work motivation, working climate on work motivation, work motivation on job satisfaction, and indirect influence of leadership on job satisfaction and indirect influence of working climate on job satisfaction. This study used quantitative approach through questionnaire with the help of employees in the Agriculture Department of Tanah Datar Regency as respondents. Data analysis used was descriptive analysis and path analysis with t-test as hypothesis testing.

The important results of research are as follows. First, leadership has a significant influence on working climate in the Agriculture Department of Tanah Datar Regency. It means that to create a good working climate it is necessary to increase the leadership role. Second, leadership has a significant influence on work motivation in the Agriculture Department of Tanah Datar Regency. This means that every improvement of leadership role will increase work motivation of Agriculture Department of Tanah Datar Regency. Third, leadership has a significant influence on job satisfaction in the Agriculture Department of Tanah Datar Regency. It means that every improvement of 
leadership role will increase job satisfaction of employees of Agriculture Department of Tanah Datar Regency. Third, working climate has a significant influence on work motivation in the Agriculture Department of Tanah Datar Regency. This means that good working climate will increase employee work motivation, and vice versa. Fourth, working climate has a significant influence on job satisfaction in the Agriculture Department of Tanah Datar Regency. It means that good working climate will increase employee job satisfaction, and vice versa. Finally, work motivation has a significant influence on job satisfaction in the Agriculture Department of Tanah Datar Regency. This means that every employee who has good work motivation then his job satisfaction will be good as well, and vice versa.

\section{Acknowledgement}

The authors extend their sincere gratitude to Adi Eka Putra, Yanda. Z, Nofa Oktalia for their contributions to this study and the data collection.

\section{References}

Baron, R. M \& Kenny, D. A. 1986. The moderator-mediator variable distinction in social psychological research: Conceptual, strategic, and statistical considerations. Journal of Personality and Social Psychology.

Brahmasari, I. A. (2008). Pengaruh motivasi kerja, kepemimpinan dan budaya organisasi terhadap kepuasan kerja karyawan serta dampaknya pada kinerja perusahaan (Studi kasus pada PT. Pei Hai International Wiratama. Thesis.

Chuang, N-K., Yin, D., \& Dellmann-Jenkins, M., (2009). Intrinsic and extrinsic factors impacting casino hotel chef's job satisfaction. Int. J. Contemp. Hospitally Management.

Conger, J. A., Kanungo, R. N., \& Menon, S. T. (2000). Charismatic leadership and follower effects. Journal of Organisational Behaviour.

Sunyoto, Danang. (2012). Teori, Kuesioner, dan Analisis Data Sumber Daya Manusia (Praktik Penelitian). Yogyakarta: CAPS.

Darmawan, Didit. (2013). Prinsip-prinsip Prilaku Organisasi. Surabaya: PT. Temprina Media Grafika.

Dubrin, Andrew J. (2005). Leadership. Second Ed. Jakarta: Prenada Media.

Galup, S. D., Klein, G., \& Jiang, J. J. (2008). The impact of job characteristics on is employee satisfaction: a comparison between permanent and temporary employees. Journal of Computer Information Systems.

George, Jennifer, George, M \& Jones, G. R. (2005). Understanding and Managing Organizational Behavior. Fifth Edition. Upper Saddle River: Pearson Prentice Hall.

Glisson, C., \& Green, P. (2006). The effects of organizational culture and climate on the access to mental health care in child welfare and juvenile justice systems. Administration and Policy in Mental Health and Mental Health Services Research, 33, 433-448.

Ho, N. T. T., Ross, H., \& Coutts, J. (2016). The influence of leadership in fisheries co management: the case of Tam Giang Lagoon, Vietnam. Society and Natural Resources.

Luthans, Fred. 2006. Perilaku Organisasi. Yogyakarta: Penerbit Andi.

Parker, C.P., Baltes, B. B., Young, S.A., Huff, J. W., Altmann, R. A., \& LaCost, H. A. (2003). Relationships between psychological climate perceptions and work outcomes: A metaanalytic review. Journal of Organizational Behavior.

Roy, F. (1989). Elaboration et Validation d'un Questionnaire Sur Le Climat De Travail. Psychologie.

Vansteenkiste, M., Simons, J., Lens, W., Sheldon, K. M., \& Deci, E. L. (2004). Motivating learning, performance and persistence: The synergistic effects of intrinsic goal contents and autonomy-supportive contexts. Journal of Personality and Social Psychology, 87, 246-260.

Wirawan. 2008. Budaya dan Iklim Organisasi. Jakarta: Salemba Empat. 